\title{
CITIZENSHIP EDUCATION OF ADULTS IN SELECTED COUNTRIES OF EUROPE - AN OVERVIEW STUDY
}

\section{[OBCIANSKE VZDELAVANIE DOSPELYCH VO VYBRANYCH KRAJINACH EUROPY - PREHLADOVA STUDIA]}

\author{
Michaela Beran Sladkayova - Jana Neusarova
}

doi: 10.18355/PG.2022.11.1.6

\begin{abstract}
The presented study focuses on the institutional provision and implementation of citizenship education in selected countries that have a developed concept of citizenship education and address this issue. At the same time, we consider these countries as examples of good practice and inspiration for the Slovak concept of citizenship education of adults, which, from our point of view, is not sufficiently developed. At the same time, it must be emphasized that citizenship education of adults is significantly influenced by the overall socio-cultural development and history of society in each country, which is also the reason why countries differ in their citizenship education of adults' models.
\end{abstract}

\section{Key words}

citizenship education of adults, education of adults, european coutries, models of citizenship education, overview study

\section{Anotácia}

Predkladaná štúdia sa zameriava na inštitucionálne zabezpečenie a realizáciu občianskeho vzdelávania vo vybraných krajinách, ktoré majú koncept občianskeho vzdelávania rozvinutý a venujú sa tejto problematike. Zároveň tieto krajiny považujeme za príklady dobrej praxe a inšpiráciu pre slovenský koncept občianskeho vzdelávania, ktorý, z nášho pohl'adu, nie je dostatočne rozvinutý. Súčasne je potrebné zdôraznit, že občianske vzdelávanie dospelých je vjednotlivých krajinách významne ovplyvnené celkovým sociokultúrnym vývojom a históriou spoločnosti, čo je aj dôvod, prečo sa medzi sebou krajiny vo svojich modeloch občianskeho vzdelávania dospelých odlišujú.

\section{Kl'účové slová}

občianske vzdelávanie dospelých, vzdelávanie dospelých, európske krajiny, modely občianskeho vzdelávania, prehl'adová štúdia

\section{1 Úvod}

Občianske vzdelávanie dospelých na Slovensku (podobne i v Českej republike), začína naberat' na dôležitosti. Avšak jeho samotná realizácia je ovplyvnená nedostatkom teoretického rozpracovania tejto problematiky 
a preto jednotlivé inštitúcie postupujú skôr nesystematicky a samotná realizácia zostáva len v rovine ,pokus - omyl.“ Aj z tohto dôvodu sme sa začali touto problematikou zaoberat' a snažíme sa ju podporit' práve z hl'adiska teoretického a metodologického rozpracovania.

Ako príklad pre inšpiráciu nám môžu slúžit' jednotlivé koncepty realizácie občianskeho vzdelávania dospelých vo vybraných krajinách Európy. Občianske vzdelávanie dospelých má v týchto krajinách hlboké korene a teda predstavuje druh vzdelávania s bohatou históriou. Práve $\mathrm{z}$ tohto dôvodu ich považujeme za akúsi inšpiráciu pri tvorbe vlastného konceptu.

\section{Nemecko}

V Nemecku sa stretávame s pojmom politické vzdelávanie (politische Bildung), ktorého ciel'ovú skupinu predstavujú deti, mládež a dospelí. Toto vzdelávanie sa rozvinulo najmä po druhej svetovej vojne, ako prevencia voči javom, ktoré napomohli k vzniku nacistického režimu (Kopecký, 2011).

Politické vzdelávanie dospelých v Nemecku je však spojené už s prijatím ústavy Weimarskej republiky v roku 1919. Na základe prijatia ústavy sa vzdelávanie dospelých stalo verejnou hodnotou a vzdelávanie dospelých má podporovat' spolková republika, jednotlivé štáty a mestá. Ústava umožnila vzdelávanie všetkým občanom, pretože vzdelaní a zodpovední občania posilňujú demokraciu (European commission, 2018a).

Občianske, resp. politické vzdelávanie, má v Nemecku teda svoju históriu a stále je považované za prioritu $v$ rámci rozvoja celej spoločnosti. Na realizácii politického vzdelávania sa $\mathrm{v}$ značnej miere podiel’a práve štát, ktorý ho aj významne financuje. Nadmerná väčšina spolkových krajín má zriadené svoje Landeszentralen für politishe Bildung. Zároveň, na celoštátnej úrovni, existuje Bundeszentrale für politische Bildung, organizácia, ktorá zastrešuje občianske vzdelávanie všetkých vekových kategórií (Kopecký, 2011). Spolková agentúra pre občianske/politické vzdelávanie je agentúrou Spolkového ministerstva vnútra, jej úlohou je prostredníctvom vzdelávania dospelých rozširovat' demokraciu a jej význam dostat' do povedomia občanov a podporovat' ich aktívnej účasti na politickom živote.

Rozvoj občianskeho vzdelávania sa datuje rokom 1945 (do tej doby išlo skôr o politické vzdelávanie), ked' bol zvrhnutý nacionálno-socialistický režim. Nemecko zažíva, v tomto období demokratický štart, ktorému však prekážal fakt, že nemecký občania mali nízke, obmedzené povedomie o demokratických procesoch a princípoch (Lange, 2008 In Beran Sládkayová \& Neusarová, 2021).

Následkom násilnej histórie sú pre Nemecko dôležitými hodnotami: demokracia, pluralita a tolerancia. Tieto základné hodnoty sa Nemecká spolková republika a agentúra snažia upevňovat' v samotných l'ud'och. Agentúra prostredníctvom rôznych publikácií, organizovaním podujatí pre občanov a uskutočňovaním vzdelávacích aktivít motivuje a oslovuje l'udí, kriticky sa zamysliet' nad otázkami, ktoré sa týkajú politického a sociálneho 
života. Na webových stránkach agentúry je množstvo tém zameraných na aktuálne problémy v samotnom Nemecku, v Európe a vo svete. Informácie, ktoré ponúka sa týkajú otázok hospodárstva, migrácie, integrácie, globalizácie, sociálnych zmien, histórie a tiež sú tu diskusie týkajúce sa nemeckej, európskej a medzinárodnej politiky. Federálna agentúra pre občianske vzdelávanie sa zúčastňuje a sama organizuje rôzne projekty, ktoré sú určené pre vzdelávatel'ov, pre rôzne spoločenské vrstvy a rôzne vekové skupiny. Agentúra financovaním partnerských spoločností zabezpečuje, aby občianske vzdelávanie bolo poskytované vo všetkých regiónoch v Nemecku (www.bpb.de).

Okrem vyššie uvedených činností organizácia vydáva publikácie a dokumenty, venuje sa výskumnej činnosti, organizuje workshopy a diskusie a zastrešuje aj internetový portál, kde sú vol’ne dostupné publikácie a metodické materiály pre rôzne skupiny poskytovatel'ov občianskeho vzdelávania v krajine.

Po prijatí ústavy sa začali zakladat' $\mathrm{v}$ Nemecku vzdelávacie inštitúcie zamerané na dospelých tzv. Volkshochschulen - Ludové vysoké školy (European Commission, 2018a). Systém vzdelávania na l’udových vysokých školách v Nemecku sa vel'mi neodlišoval od vzdelávacieho systému v Dánsku. Vzdelávacie programy v týchto školách sa orientovali na potreby ludí, na ich aktívne zapájanie sa do vzdelávania a boli určené pre všetkých občanov, bez rozdielu postavenia $\mathrm{v}$ spoločnosti.

Ked’že sa univerzity orientovali na slobodu a demokraciu, nacistické obdobie a 2. svetová vojna spôsobili, že mnoho týchto centier bolo zrušených, alebo pozastavili svoje pôsobenie. Po skončení vojny sa postupne centrá vzdelávania dospelých začali obnovovat', aby mohli byt' l'udia informovaní o dianí v spoločnosti a aby sa prostredníctvom vzdelávania predchádzalo opakovaniu histórie. Rozdelením krajiny na Západné a Východné Nemecko sa rozdelila aj ideológia $v$ l'udových vysokých školách, začali sa vyvíjat' dvomi smermi. Na východnej strane Nemecka $v$ tom čase existoval socialistický systém vzdelávania a vzdelávanie $\mathrm{v}$ centrách bolo zamerané na odbornú prípravu. V západnej časti Nemecka sa inštitúcie vzdelávania dospelých snažili orientovat' na pôvodné hodnoty a v 80 . rokoch rozšírili kurzy o vzdelávanie pre negramotných. Po roku 1989, po zjednotení krajiny sa stali l'udové vysoké školy súčast'ou Deutschen Volkshochschul-Verband - Nemecké l'udové vysoké školy - združenie.

V súčasnosti má združenie svoje zastúpenie v každej spolkovej republike a zastupuje svoje záujmy a záujmy občanov na politickej úrovni. V univerzitách pracujú pedagogický pracovníci, dobrovolníci a administratívny pracovníci. Vzdelávacie programy, ktoré poskytujú centrá sú zamerané na rôzne oblasti napr.: integrácia, politické vzdelávanie, kultúrne vzdelávanie, gramotnost', zdravie a jazyky. V dôsledku integrácie cudzincov do spoločnosti, štát a spolkové republiky povolili vykonávat' pre pristahovalcov do Nemecka záverečné testy $\mathrm{z}$ integračných kurzov, ktoré sú jednou z podmienok pri získaní občianstva (Schneider, 2019 In Beran Sládkayová \& Slavonic Pedagogical Studies Journal, eISSN 1339-9055, ISSN 1339-8660, Volume 11 Issue 1, 2022 
Neusarová, 2021). Účastníci si môžu v kurzoch doplnit’ a prehíbit' odborné znalosti a taktiež majú možnost' získat' novú kvalifikáciu.

Medzi d’alšie organizácie poskytujúce politické vzdelávanie dospelých môžeme zaradit' cirkevné inštitúcie a organizácie tretieho sektora (napr.: Nemecká spolková pracovná skupina pre katolicke vzdelávanie dospelých, Nemecká evanjelická pracovná skupina pre vzdelávanie dospelých, Nemecký inštitút pre vzdelávanie dospelých Leibnizove centrum pre celoživotné učenie, a iné). Všetky organizácie sú podporované a financované štátom (EAEA, 2011, pp. 9-11).

Špecifického poskytovatel'a politického/občianskeho vzdelávania predstavuje Pracovná skupina nemeckých vzdelávacích inštitúcií. Inštitúcia bola založená v roku 1959 a zastrešuje spoločnosti, ktoré svoju činnost' sústred’ujú na mládež a dospelých. Venujú sa neformálnemu politickému/občianskemu, medzinárodnému a medzikultúrnemu vzdelávaniu mládeže a dospelých. Občianske vzdelávanie v týchto inštitúciách je orientované na súčasné témy ako je demokracia, l’udské práva, emancipácia a kritické myslenie. Inštitúcia spolupracuje s národnými a medzinárodnými organizáciami, organizuje školenia a odborné konferencie a vydáva rôzne publikácie (www.adb.de).

Základnou súčast'ou demokracie v Nemecku je občianska výchova. Hlavnými ciel'mi občianskeho vzdelávania dospelých sú:

- zabezpečenie jednotlivcovi získanie vedomostí a zručností potrebných pri utváraní nezávislého názoru a prijímaní správnych rozhodnutí,

- poskytnutie možností človeku zamysliet' sa nad vlastnou situáciou, plnit' si povinnosti voči spoločnosti a aktívne sa zúčastňovat' na politických a sociálnych procesoch v spoločnosti (www.bmi.bund.de). $\mathrm{Na}$ základe toho, že Nemecko je rozdelené na 16 spolkových krajín sa môžeme domnievat', že aj občianske vzdelávanie dospelých v každom štáte bude mat' iné priority vo vzdelávaní, ale rovnaký ciel': aktívna účast' občanov na politickom a spoločenskom živote a upevňovanie demokracie.

Môžeme konštatovat', podl'a Langa (2008 In Beran Sládkayová \& Neusarová, 2021), že medzi stále aktuálne výzvy pre nemecké občianske vzdelávanie dospelých patrí rozvoj samostatnej, výskumne orientovanej vedeckej disciplíny. Táto disciplína v sebe zahŕña štyri rôzne polohy:

- pokus o obnovenie politickej vedy ako centrálnej disciplíny v špecifikovaných didaktikách,

- dat' rôznym oblastiam spoločenských vied rovnaké postavenie a význam v rámci občianskeho vzdelávania,

- rozvíjat' demokratický diskurz na rôznych úrovniach,

- zdôraznenie didaktické prvenstvo samotného učiaceho sa a jeho očakávania a rozvoj profesionálnej perspektívy v rámci kategórie politického vedomia. 
Ciel'om takéhoto vzdelávania je naučit' študentov/účastníkov vzdelávania/občanov rozpoznávat' sociálno-politickú realitu, ako aj to, ako túto realitu posudzovat' a zároveň ovplyvňovat'. Jeho ciel'om je taktiež tréning spoločensko-politického vedomia tak, aby sa zo študenta/účastníka vzdelávania stal autonómny a politicky vyspelý občan.

\section{Pol'sko}

Občianske vzdelávanie v Pol'sku siaha až do roku 1773. V tomto období bolo založené prvé ministerstvo školstva $\mathrm{v}$ Európe - Národná komisia pre vzdelávanie a týmto krokom vzdelávanie nadobudlo občiansky a politický charakter. Situácia $v$ krajine neumožnila túto formu vzdelávania uskutočnit' priamo v praxi, pretože Pol'sko stratilo samostatnost'. Občianske vzdelávanie dospelých našlo svoje opodstatnenie až v 19. a 20. storočí. Dôležitou osobou v občianskom vzdelávaní dospelých je Zygmunt Balicki, ktorý bol toho názoru, že občianske vzdelávanie má byt' súčast'ou vzdelávacieho systému $\mathrm{v}$ krajine. Úlohou občianskeho vzdelávania dospelých $\mathrm{v}$ tomto období bolo vyučit' takých vojakov, ktorí bojujú za práva a slobodu utláčaného národa. Významnou predstavitel'kou, ktorá prispela $\mathrm{v}$ značnej miere do občianskeho vzdelávania dospelých bola Helena Radlinská. H. Radlinská, bola predstavitel'kou sociálnej pedagogiky a do vzdelávacej koncepcie v tejto krajine zahrnula znaky sociálneho a kultúrneho rozvoja, týkajúceho sa všetkých obyvatel'ov Pol'ska. Občianske vzdelávanie dospelých v medzivojnovom období bolo orientované na dospelých - vojakov a občianska výchova sa začala vyučovat' $\mathrm{v}$ školskom systéme vzdelávania. V rokoch 1949 - 1989 sa občianske vzdelávanie dospelých uskutočňovalo v dvoch smeroch, prvý smer určoval štát a druhý smer bol ovplyvňovaný politickou opozíciou. Śtát zastával názor, že výchova je prvkom politiky, ale vykonávaná je prostredníctvom nepolitických orgánov. Vzdelávanie spojené s politikou zaručovalo úspech a rozvoj osobnosti. Na druhej strane politická opozícia považovala občianske vzdelávanie dospelých ako prostriedok v boji proti nevhodnému využívaniu moci v krajine. Po roku 1989 sa hlavným prvkom vzdelávania stala demokracia a vzdelávanie má prispievat' ku konštituovaniu zodpovednej a demokratickej občianskej spoločnosti. Uskutočňovanie vzdelávacích ciel’ov, narazilo na prekážky ako sú: materiálne zabezpečenie, určenie kompetencií a prekážkou sa stali aj globálne zmeny (Rocznik Andragogiczny, 2007 In Beran Sládkayová \& Neusarová, 2021).

V súčasnosti poskytovanie občianskeho vzdelávania dospelých výrazne zastupuje tretí sektor. Do inštitúcií, ktoré poskytujú občianske vzdelávanie dospelých môžeme zaradit' aj vysoké l'udové školy zriadené na území tejto krajiny. Vláda sa zaviazala výrazne podporit' tretí sektor a vysoké l'udové školy, založením Národného inštitútu slobody. Inštitúcia je zriadená pri úrade predsedu vlády a podporuje rozvoj občianskej spoločnosti, verejnoprospešných aktivít a dobrovol'níctva (www.gov.pl).

Medzi mimovládne organizácie, ktoré sa venujú demokracii, občianskym aktivitám a teda občianskemu vzdelávaniu dospelých môžeme zaradit' napr.: Združenie na rozhraní výskumu a vzdelávania, Inštitút pre verejné otázky, 
Spoločnost' pre antidiskriminačné vzdelávanie, a iné. Federálnou organizáciou je Skupina Zagranica, ktorá združuje mimovládne organizácie zamerané na podporu demokracie, globálneho vzdelávania, humanitárnej pomoci a spolupracujú s inými krajinami (www.zagranica.org.pl). Môžeme sem zaradit' aj združenia, ktoré poskytujú sociálnu pomoc, výchovu a vzdelávanie voblasti l'udských práv a demokracie pre marginalizované skupiny obyvatel'stva.

V Pol'sku majú svoju históriu aj l’udové školy, ktorá siaha do roku 1900, kedy sa za prvé l'udové školy považovali pol'nohospodárske školy zriadené v tejto krajine. Vzhl'adom na to, že školy vznikli na území, o ktoré prebiehali v tom čase spory, ich možnosti na uplatnenie Grundtvigových myšlienok boli obmedzené. Prvé uznávané l'udové univerzity začali vznikat' až po roku 1921, ich zakladatel'om bol kňaz A. Ludwiczak. Hlavnými dôvodmi vzniku l'udových vysokých škôl bola vysoká negramotnost' obyvatel'ov a ich negatívny postoj $\mathrm{k}$ duchovným a materiálnym hodnotám tohto národa. Podmienkou prijatia na l'udové vysoké školy bolo dosiahnutie 18 rokov. Vzdelávanie sa sústredilo na oblasti ako: história, astronómia, spev, ekonomika, literatúra a iné. Základnou myšlienkou l’udových vysokých škôl bolo, pripravit' občanov na aktívny spôsob života vo svojej komunite a viest' ich k zodpovednému občianstvu. Po skončení 2. svetovej vojny a v období transformácie boli niektoré univerzity zlikvidované. Univerzitám, ktoré nezrušili svoje pôsobenie sa nepodarilo dosiahnut' také významné postavenie, ako mali v období pred vojnou. Dôležitými faktormi, ktoré ovplyvňujú existenciu l'udových vysokých škôl v Pol'sku sú, nízka účast' dospelých na vzdelávaní a právne definovanie l'udových univerzít v systéme vzdelávania dospelých (Domańsky, 2017 In Beran Sládkayová \& Neusarová, 2021).

Ďalším poskytovatel'om občianskeho vzdelávania je Fundacija civic polonus. Nadácia vznikla v roku 1995. Hlavným ciel’om nadácie je ,Rozvoj občianskych postojov umožňujúcich jednotlivcovi aktívne sa zúčastňovat' na verejnom živote“" (www.civispolonus.org.pl).

Organizácia pôsobí na národnej a medzinárodnej úrovni. Činnost' spoločnosti je zameraná na mládež a dospelých l'udí, ktorí majú záujem zmenit' život v komunite, v ktorej žijú a v podstate podiel'at' sa na rozvoji spoločnosti v celom štáte. Poskytuje vzdelávanie pedagogickým pracovníkom voblasti občianskej výchovy. Svoj ciel' dosahuje organizovaním a financovaním vlastných vzdelávacích programov, organizovaním medzinárodných konferencií a vydávaním učebných materiálov. Spolupracuje so vzdelávacími, vedeckými a spoločenskými organizáciami, ktoré aktívne podporujú rozvoj občianskeho vzdelávania dospelých. V školách a mestách organizuje programy zamerané na šírenie poznatkov o občianskom vzdelávaní, l'udských právach, demokracii a tolerancii. Vzdelávanie nadácia uskutočňuje formou skupinovej práce, seminárov, konferencií, workshopov a školení. Spoluprácou s ostatnými mimovládnymi organizáciami posilňuje oblast' občianskeho vzdelávania 
a taktiež sa snaží o to, aby občianske vzdelávanie bolo súčast’ou vzdelávacieho systému v Pol'sku (www.civispolonus.org.pl).

\section{Francúzsko}

Francúzsko patrí medzi krajiny so silnou tradíciou vzdelávania dospelých a s ohl'adom na historicko-kultúrny kontext taktiež s relatívne silnou históriou občianskeho vzdelávania dospelých. O ideách a možnostiach celoživotného učenia hovoril, krátko po Vel'kej francúzskej revolúcii v roku 1789 na Národnom zhromaždení, osvietenský filozof, politik, matematik a encyklopedista Jean Antoine Nicolas de Condorcet. Už v 18. storočí jeho návrhy obsahovali nasledujúce myšlienky, ktoré sú $\mathrm{z}$ pohl'adu súčasnej koncepcie celoživotného učenia dobre známe a dodnes uznávané:

- vzdelávacie príležitostí by mali byt' prístupné všetkým občanom v priebehu celého života;

- jednotlivci by mali byt' vedení k rozvoju svojho talentu, aby mohli plne rozvíjat' svoje občianstvo a zdokonal'ovat' svoje schopnosti (upravené podl'a Condorcet In European Commission, 2018b).

Tieto myšlienky vychádzajú ideovo, okrem iného, z vtedajšej Deklarácie práv človeka a občana $\mathrm{z}$ roku 1789 , ktorá sa stala základnou listinou pre následné určenie základných práv a slobôd a stavebným kameňom súčasnej európskej demokracie. ${ }^{1}$ Z Deklarácie práv človeka a občana vychádza aj neskoršia nová francúzska ústava (z roku 1791), ktorá zaručovala rovnost' občanov, slobodu slova a právo na vlastníctvo (Informačné centrum Vlády ČR, 2009).

$\mathrm{Na}$ začiatku 19. storočia zásadnú rolu, vo formovaní hodnôt aktívneho občianstva a l'udských práv vo Francúzsku, zohral vznik občianskeho zákonníka Code civil ${ }^{2}$ z roku 1804, ktorý sa opieral o hodnoty vol'nosti, rovnosti a bratstva a zmenil predchádzajúce spoločenské a politické usporiadanie. Ideovo sa Code civil opieral o prirodzené právo s jasnými prvkami práva rímskeho a i napriek častým novelizáciám je základom súčasnej občianskej spoločnosti Francúzska (epravo.cz, 2018). Stal sa tak inšpiráciou pre neskoršie občianske zákonníky okolitých štátov, takže silno ovplyvnil aj d’alšie štáty Európy. Hodnoty aktívneho občianstva a demokracie sú tak vo francúzsku silno zakorenené a občianske sebavedomie Francúzom nechýba.

Hlavné inštitúcie celoživotného vzdelávania/učenia boli založené pred mnohými rokmi. Z oblasti d'alšieho vzdelávania dospelých môžeme hovorit' o napríklad o Conservatoire national des arts et métiers, známou pod skratkou CNAM založenou v roku 1794 a Agence nationale pour la formation professionnelle des adultes známou pod skratkou AFPA (založená a vybudovaná v rokoch 1946 - 1949). Obidve inštitúcie sú silno zamerané na odbornú prípravu dospelých. Slúžia predovšetkým potrebám pracovníkov a d'alším ekonomicky aktívnym jednotlivcom. Bez d'alšieho vzdelávania by

1S dokumentom sa je možné zoznámit’ napríklad tu:

https://icv.vlada.cz/assets/udalosti/Deklarace-prav-lidskych-a-obcanskych.pdf

2 V plnom názve - Code civil des Francais

Slavonic Pedagogical Studies Journal, eISSN 1339-9055, ISSN 1339-8660, Volume 11 Issue 1, 2022 
sa l'udia stali t'ažko zamestnatel'nými a uplatnitel'nými na trhu práce aj v občianskej spoločnosti. To si Francúzsko uvedomuje, aj s ohl'adom na svoj predchádzajúci vývoj a relatívnu početnost' nízko kvalifikovaných občanov. $\mathrm{Aj} \mathrm{z}$ tohto dôvodu podstúpilo a zrealizovalo Francúzsko mnoho reforiem. Boom a expanziu vzdelávania dospelých zaznamenalo Francúzsko po II. svetovej vojne, najvýraznejšie reformy vzdelávania dospelých bolo možno pozorovat' $v$ 70. a 90 . rokoch 20 storočia.

Ich výstupom bol, mimo iného, vznik kvalitného C-VET systému („Continuing vocational education and training"), ktorý rozvíja d’alšie odborné vzdelávanie a výcvik v pracovnom prostredí, na ktorom sa významne podielajú zamestnávatelia. Aktuálnou témou je napríklad odborná príprava pracovníkov (znovu)vstupujúcich na trh práce. Systém C-VET je súčasne jadrom legislatívneho procesu vo vzdelávaní dospelých od roku 1971 (European Commission, 2018b).

Francúzsko v súčasnosti ide cestou na seba nadväzujúcich d’alších reforiem., ktoré sú charakteristické decentralizáciou v prospech rozdel'ovania právomocí smerom k regionálnym inštitúciám a celkom (European Commission, 2018b) pod koordináciou Ministerstva národného vzdelávania, mládeže a športu a Ministerstva práce, zamestnanosti a ekonomického začleňovania.

Taktiež je možné sledovat' intenzívnu spoluprácu medzi akademickou a výskumnou sférou, ktorá umožňuje prenos poznatkov z vedy a výskumu do vzdelávacieho procesu pre stredné školy. „Do projektu je zapojených 120 akademických tímov a takmer 500 učitelov, ktorí experimentujú a pilotujú nové vyučovacie metódy a vytvárajú vzorové scenáre“, ktoré následne zhromažd’uj v databázy EDUbase (Pilný, 2020, p. 124).

Francúzsko kladie, v súlade s modernými aktuálnymi trendami, vo svojej vzdelávacej politike vel'ký dôraz práve na digitálne inovatívne vzdelávanie a s tým spojené typy gramotnosti (ako je napríklad digitálna gramotnost'). Kvalitní digitálny obsah má byt' prístupný bezpečne, odkial'kol'vek a na akomkol'vek zariadení. Francúzsko využíva vzdelávacie portály, napríklad Éduthéque so vzdelávacím obsahom $\mathrm{z}$ televízie, kultúrnych a vzdelávacích inštitúcií.

Vo Francúzsku existuje v súčasnej dobe projekt ERAM ulahčujúci prístup $\mathrm{k}$ digitálnemu vzdelávaniu, obzvlášt’ školám prostredníctvom Virtual Learning Environment (d’alej iba „VLE“). Okrem iného je výstupom spolupráce všetkých účastníkov a záujmových organizácií zhromaždených okolo jedného projektu pre všetkých vydavatel'ov vzdelávacích obsahov a VLE. Zverejňuje príručky, encyklopédie, učebnice a multimediálny obsah. Rieši však taktiež otázku ochrany osobných dát. Je previazaný sériou workshopov a seminárov k osvojeniu užívania a nutnej administratívy. 
Z postupov, ktoré Francúzsko preferuje, je možné konštatovat', že vychádzajú do značnej miery $\mathrm{z}$ koncepcie vedomostného managementu a učiacej sa spoločnosti ${ }^{3}$ a snaží sa o cielené zdokonal'ovanie práce s informáciami. L'udia v rôznych odboroch a oblastiach budú nútení kontinuálne prijímat, vyhodnocovat' a spracovávat' nové informácie, poznatky a vzdelávat'sa, aby obstáli $\mathrm{v}$ rýchlo meniacom sa spoločenskom prostredí. Niektoré tradičné odbory a povolania budú zanikat' a iné, nové, postavené na nových princípoch budú naopak vznikat' (Vymětal, Diačiková \& Váchová, 2005).

Taktiež aktívny občiansky život vo Francúzsku sa teda nezaobíde bez digitálneho vzdelávania. Francúzsko preto podporuje občiansku výchovu a vlastenectvo prostredníctvom portálu ENI, ktorý spája 27 iniciatív pre vekovú skupinu 11 - 14 rokov. Portál facilituje orientáciu v základných $\mathrm{v}$ informačných a dokumentačných zdrojoch a prístup $\mathrm{k}$ legálnemu a eticky zameranému obsahu. Ako príklad dobrej praxe môže byt' vnímaná prepojenost' tohto portálu s francúzskymi médiami, obzvlášt' $\mathrm{s}$ televíziou CNIL (Commission Nationale de l'Informatique et des Libertés), France Media Monde a d'alšími pre čo najväššiu možnost' propagácie a šírenia informácií o možnostiach tohto portálu (Pilný, 2020).

Ďalšia občianska iniciatíva je obrázková knižka pre rodičov „La famille Tout - Ecran“, ktorá je vo Francúzsku využívaná ako nástroj pre šírenie informácií týkajúcich sa rodinnej výchovy a súžitia (Pilný, 2020).

Dôležitú úlohu v občianskom vzdelávaní detí, mládeže a dospelých plní ludovýchovné vzdelávanie, ktoré má vo Francúzsku vel'mi silnú tradíciu a je realizované občianskou spoločnost'ou prostredníctvom rady asociácií a hnutí. Ako príklad je možné, na tomto mieste, uviest' asociáciu La Ligue de l' Enseignement (https://laligue.org). Liga vznikla už v roku 1866 a bola založená Jeanom Macé, francúzskym učitel’om, novinárom a politikom. Podporuje najmä hodnoty bratstva, solidarity, demokracie, všeobecného ludstva, ale taktiež dobrovol'níctvo. Na webových stránkach sú uvedené aktuálne témy, ktorými sa asociácia, respektíve jej jednotlivé regionálne federácie a spolky, venuje pre všetky vekové skupiny (zameriava sa teda aj na detí, mládež a dospelých).

Okrem organizačných informácií týkajúcich sa fungovania vo federáciách ligy, web zoznamuje so sekciami týkajúcimi sa občianstva a medzinárodnej spolupráce, kultúry a poznania kultúrneho dedičstva, športu, dobrovol'níctva, pobytu detí v prírode a ochrane životného prostredia, ako aj ochrany zdravia občanov vrátane problematiky týkajúcej sa prevencie šírenia COVID - 19 a aktuálnych protiepidemiologických opatrení. Liga zoznamuje s radou tuzemských či európskych projektov, do ktorých sa môžu občania zapojit'. Prostredníctvom svojich zástupcov sa zúčastňuje verejného aj politického života, organizuje petície, píše manifesty k rôznym témam, zoznamuje

3 resp. učiacej sa organizácie tak, ako ju poznáme napríklad z diela amerického vedca Petera M. Sengeho: „The Fifth discipline“ (Piata disciplína) z roku 1990

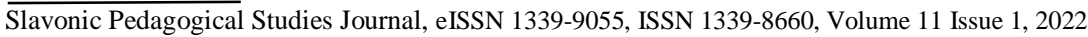


s príbehmi l'udí (najmä mladých), ktorí sa zapojili do dobrovol'níckych projektov (často ide o l'udí z radov prist’ahovalcov pre podporenie kultúrnej diverzity).

Dôležitou témou je aj osveta $\mathrm{v}$ problematike vzniku predsudkov a stereotypov a s tým spojená prevencia rasizmu, teda pracuje aj s tematikou interkultúrneho vzdelávania (respektíve multikultúrnej výchovy). Zoznamuje s občiansky zameranými témami pre deti, mládež, rodičov a d’alších dospelých, $\mathrm{k}$ čomu využíva rôzne akcie a taktiež tvorbu filmov, publikačnú činnost', tvorbu aplikácií a pozvánok pre verejnost'. Nadväzuje taktiež na významné dni a francúzske štátne sviatky, ktorými približuje verejnosti kultúrne dedičstvo a významné historické momenty francúzskych dejín. Liga organizuje dobrovolníkov, ktorý využívajú svoje schopnosti a schopnosti $\mathrm{v}$ prospech občianskej spoločnosti a všeobecne podporuje princíp participácie laikov na verejnom živote $\mathrm{v}$ rôznych oblastiach života. Podporuje tak v rámci osvety a vzdelávania záujmové a občianske aktivity, taktiež vd’aka intenzívnej spolupráci so školami, knižnicami a d’alšími inštitúciami podielajúcimi sa na podpore aktívneho občianstva (La Lique de 1' Enseignement, online, n.d.).

\section{Slovinsko}

Slovinsko patrí medzi krajiny s relatívne bohatou tradíciou vzdelávania dospelých a andragogiky, avšak Slovinský štát nemá od roku 1990 vlastnú strategickú politiku občianskeho vzdelávania dospelých. Túto oblast' nachádzame napríklad $\mathrm{v}$ hraničných formách vzdelávania dospelých (napríklad univerzity tretieho veku alebo študijné krúžky) a je viazaná na oblast' neziskových organizácií. Zákon o vzdelávaní dospelých problematiku občianskeho vzdelávania dospelých priamo nerieši.

V oblasti vedeckého výskumu i európskej spolupráce je Slovinsko však zapojené relatívne silne. Slovinsko sa napríklad v minulosti zúčastnilo výskumného projektu $\mathrm{ETGACE}^{4}$, ktorý analyzoval to, ako sa dospelí Európania naučili aktívnemu občianstvu a aké faktory vedú k efektívnemu formálnemu, neformálnemu a informálnemu občianskemu vzdelávaniu alebo projektu Vzdelávanie $\mathrm{k}$ demokracii, ktorý sa odohrával v rámci programu PHARE ${ }^{5 .}$ Národné programy pre vzdelávanie dospelých sa pravidelne hlásia, mimo iného, k Lisabonskej stratégii (upravené podl’a Kopecký, 2011).

V Slovinsku pôsobí v oblasti vzdelávania dospelých (obsahujúci aj tematiku občianskeho vzdelávania dospelých) verejná inštitúcia Andragogické centrum Slovinskej republiky (www.acs.si ${ }^{6}$ ), ktorá vznikla v septembri $\mathrm{v}$ roku $1991 \mathrm{~s}$ ciel’om vyvíjat' platformu vzdelávania dospelých $\mathrm{v}$ Slovinsku. V súčasnej dobe sa jeho činnost' riadi Uznesením o národnom vzdelávacom programe v Slovinskej republike (na obdobie 2013 - 2020) a d’alšími národnými a európskymi strategickými dokumentmi a rozvojovými

\footnotetext{
4 Education and training for governance and active citizenship in Europe: analysis of adult learning and design of formal, non-formal and informal educational intervention strategies 5 Poland and Hungary: Aid for the Restructuring of Economies program

6 Používá se též zkratka SIAE - Slovenian Institute for Adult Education - v anglickém překladu
} 
smernicami vo vzdelávaní dospelých. Kompetencie a zodpovednost' centra sú upravené taktiež právnymi predpismi vo vzdelávaní, najmä zákonom o organizácií a financovaní školstva a zákonom o vzdelávaní dospelých z roku 2018. ${ }^{7}$ Pokial' hovoríme o zábere tejto inštitúcie v rámci riešenia problematiky občianskeho vzdelávania dospelých, tak prispieva $\mathrm{k}$ zvyšovaniu povedomia o prístupnosti a dôležitosti, celoživotného učenia a neformálne získaných vedomostí, ktoré zvyšujú kvalitu života jednotlivca a zlepšenie spoločnosti ako celku.

Od roku 2012 pôsobí Andragogické centrum Slovinskej republiky taktiež ako národný koordinátor Európskeho programu pre vzdelávanie dospelých (EAAL). Prostredníctvom rôznych výskumov, programov, projektov a akcií spolupracuje na podpore kultúry celoživotného učenia a vzdelávania dospelých. Centrum dbá o výmenu informácií medzi domácou, medzinárodnou, odbornou aj širokou verejnost'ou, ktorá sa venuje tvorbe politík na národnej aj nadnárodnej úrovni a zapája sa a propaguje po profesionálnej stránke inštitúcie vzdelávania dospelých vrátane záujemcov o vzdelávanie dospelých $\mathrm{z}$ radov jednotlivcov (Andragoški centrum Republike Slovenije, 2021).

Centrum na svojich webových stránkach d’alej uvádza, že organizuje viac ako 40 vzdelávacích programov ročne pre približne 800 účastníkov (andragógov). Základom pre úspešné zapojenie účastníkov do programu sú výskumné a vývojové projekty založené na aktuálnych spoločenských témach doma i v zahraničí. V súlade s princípmi nízkoprahovosti v poskytovaní služieb centrum usiluje taktiež o dostupnosti vzdelávania pre dospelých $\mathrm{z}$ radov znevýhodnených skupín občanov, rozvíjajú poradenstvo a hodnotenie a zdokonal'uje svoje vzdelávacie programy v oblasti kvality (Andragoški centrum Republike Slovenije, 2021). Andragogické centrum Slovinskej republiky je taktiež členom EPALE a hlási sa k aktuálnym spoločenským témam, v súlade s politikou Európskej únie. Rok 2021 sa totiž aj v Slovinsku nesie $\mathrm{v}$ duchu rozvoja digitálnej gramotnosti a digitálneho vzdelávania, ako aj v d'alších krajinách Európy.

Z posledných dokumentov je zrejmé, že sa situácia vzdelávania dospelých, vrátane občianskeho vzdelávania dospelých v Slovinsku, vyvíja teda relatívne dobre. Slovinsko má napríklad vysoký počet dospelých l'udí vo vekovom rozmedzí $30-34$ rokov, ktorí sa zúčastňujú terciárneho vzdelávania ( $\mathrm{v}$ porovnaní s európskym priemerom malo už v roku 2016 o 4,2\% viac). Pokial' ide o účast' na neformálnom vzdelávaní, aj v tomto segmente pozorujeme narastajúci trend, aj vzhl’adom $\mathrm{k}$ zvyšujúcemu sa počtu účastníkov na neformálnom vzdelávaní vo veku 20 - 64 rokov. Napríklad kompletná správa Európskej únie o Slovinsku z roku 2017 uvádza, že efektivitu systému vzdelávania dospelých umožňuje celistvá siet' verejných poskytovatel'ov a primerane usporiadaná štruktúra rozhodujúcich činitel'ov. Súčasne Slovinsko bojuje s relatívne vysokou nezamestnanost'ou (obzvlášt'

7 Teda zákon o izobraževanju odraslih z_roku 2018

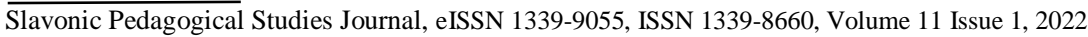


u žien okolo 50 rokov) a s nedostatkom pracovných miest, čo je pre Slovinsko výzva $\mathrm{k}$ riešeniu tohto problému na d’alšie budúce obdobie (European Commission, 2018c).

Podla Sardoča môžeme za ciel' občianskeho vzdelávania považovat' naučit' študentov/účastníkov vzdelávania o problémoch, témach, ktoré sú najdôležitejšie pre formovanie občana a podstatné pre aktívne občianstvo. Okrem toho môžeme ciel' občianskeho vzdelávania definovat' cez tri oblasti:

- demokracia, právny poriadok a inštitucionálne zabezpečenie;

- l'udské práva;

- rovnost' a rozmanitost' (Sardoč, 2005 In Beran Sládkayová \& Neusarová, 2021).

Autor rovnako hovorí aj kompetenciách, ktoré je možné získat' prostredníctvom občianskeho vzdelávania dospelých. Tieto kompetencie môžeme rozdelit' na tri skupiny:

- kognitívne - vedomosti o pravidlách života $v$ miestnej a širšej komunite, vedomosti týkajúce sa právomocí $\mathrm{v}$ demokratickej spoločnosti, vedomosti o princípoch a hodnotách o l'udských právach a demokratickom občianstve;

- afektívne - zahŕňajú etické kompetencie a hodnoty;

- sociálne - schopnost' žit' s inými l'ud'mi, riešit' konflikty demokratickým spôsobom, aktívne sa zúčastňovat' na veciach verejných (Sardoč, 2005 In Beran Sládkayová \& Neusarová, 2021).

Dovolíme si konštatovat', že tieto kompetencie ako aj formulácia samotného ciela do značnej miery kopíruje aktuálne nastavené medzinárodné trendy $\mathrm{v}$ rámci rozvoja občianskeho vzdelávania nie len dospelých, ale aj detí a mládeže.

\section{Dánsko}

Dánsko má bohatú históriu občianskeho vzdelávania, preto môže byt' z hladiska modelov občianskeho vzdelávania dospelých inšpiráciou aj pre d’alšie európske štáty. Pre občianske vzdelávanie sa v Dánsku tradične používajú pôvodné dánske pojmy ako je: folkeoplysning a folkestyre, ktoré by sme mohli preložit' ako osveta (či l'udovýchova) a demokracia. Andragogicky zaužívanejšie pojmy citizenship education a lifelong learning, resp. jeho dánske obdoby začali byt' $v$ politických dokumentoch použivané až na začiatku 21. storočia (Kopecký, 2011).

Tradícia občianskeho vzdelávania je v Dánsku spätá s pôsobením filozofa, teológia a vzdelávatel'a Nikolaja Frederika Severina Grundtviga (1783-1872), ktorý je dôležitou osobnost'ou v dánskom vzdelávacom systéme. Grundtvig žil v revolučnom období, čo ho podnietilo k tomu, aby sa na znovu vytvorení spoločnosti podiel'alo čo najviac obyvatel'ov. Jeho ciel'om bolo informovat' širokú verejnost' o možnostiach, ktoré prispejú $\mathrm{k}$ lepšiemu životu občanov a podnecovat' ich k účasti na tvorbe spoločnosti. Svojimi myšlienkami prispel $\mathrm{k}$ rozvoju občianskeho vzdelávania dospelých $\mathrm{v}$ Dánsku. Na základe jeho myslenia a práce, neskôr začali vznikat' l'udové vysoké školy, ktoré sú 
považované za tradíciu a sú zamerané na dospelých občanov. Škola má učit' svojich študentov ako byt' dobrým občanom. Ludové univerzity $\mathrm{v}$ porevolučných a povojnových rokoch boli určené pre menej vzdelaných občanov, aby sa mohli plnohodnotne zúčastnit' na spoločenskom živote. L'udové vysoké školy predstavujú dôležitú súčast' neformálneho vzdelávania a ponúkajú krátkodobé aj dlhodobé kurzy, ktoré sú zamerané na politiku, osobný rozvoj a umenie (Kopecký, 2011).

Vysoké l'udové školy sa prispôsobovali a aj sa prispôsobujú aktuálnym spoločenským potrebám a sú zamerané na praktickú činnost' študentov, sú to internátne školy, na ktorých sa vzdeláva diskusným systémom. Študenti sa počas doby trvania kurzu zapájajú do rôznych vzdelávacích aktivít a podiel'ajú sa na rôznych spoločenských činnostiach organizovaných v školách. Je dôležité poznamenat', že tieto l’udové školy nemajú skúšky a ani nie sú ukončené oficiálnym dokladom. Dnes pôsobí v Dánsku približne 70 l’udových vysokých škôl (www.hojskolerne.dk).

Grundtvig chápal rozdiely vo vzdelávaní medzi det'mi a dospelými a chcel dosiahnut' aby vzdelávanie bolo bezplatné pre všetkých. Vedel, že študenti, ktorí navštevujú tieto školy chcú byt' aktívny v spoločenskom a politickom živote. Vedel aj to, že každý má skúsenosti z vlastného života, ktoré môže vhodne využit'. Model vysokých l'udových škôl od Dánska postupne prebralo viacero krajín, avšak vzdelávacie programy si prispôsobili podmienkam vo svojej krajine.

V Dánsku samotné občianske vzdelávanie dospelých pramenilo, okrem l'udových vysokých škôl, aj z dánskeho vzdelávacieho hnutia nezávislého na štáte a reagovalo na ohrozenie dánskej samostatnosti a kultúrnej svojbytnosti. Intenzívnym impulzom pre rozvoj l'udovýchovného hnutia bola okupácia krajín počas druhej svetovej vojny. Tá prispela $\mathrm{k}$ rozvoju schopností sebaorganizácie a sebariadenia občianskej spoločnosti, najmä v oblasti dobrovol'níctva.

Prvé zákony na podporu občianskeho vzdelávania pochádzajú z 30. rokov 20 . storočia. Ďalšiu vlnu spoločenského a politického záujmu o občianske vzdelávanie dospelých je možné pozorovat' v 80. rokoch minulého storočia (Kopecký, 2011).

V rámci dánskeho systému vzdelávania dospelých sa stretávame s dvomi štruktúrami. Tá prvá sa dotýka formálneho systému vzdelávania dospelých, ktorý sa člení do troch skupín:

- všeobecné vzdelávanie dospelých (vzdelávanie zamerané na získavanie kompetencií),

- prípravné vzdelávanie dospelých (základné zručnosti v písaní, čítaní a matematike),

- vzdelávanie migrantov (dánčina, dánska kultúra a spoločnost', pre tých, ktorí chcú požiadat' o občianstvo) (EAEA, 2011). 
Druhú štruktúru vzdelávania dospelých tvorí neformálne vzdelávanie, do ktorého je zarad'ované aj občianske vzdelávanie dospelých. Základom občianskeho vzdelávania dospelých v Dánsku sú l'udové vysoké školy. Tieto školy sa zameriavajú na neformálne vzdelávanie a vzdelávanie je vnímané ako prostriedok sociálnej integrácie, teda posilnenie solidarity a súdržnosti medzi l'ud'mi (Kopecký, 2011). Zároveň sú založené na myšlienkach Gruntviga, ako už bolo uvedené vyššie, tak ako vo väčšine škandinávskych krajín. Tieto vysoké školy ponúkajú rezidenčné kurzy, ktoré sa vyznačujú vzájomným vzdelávaním, akceptáciou predchádzajúcich skúseností a malým množstvom formálnych skúšok (EAEA, 2011).

Jednotlivých poskytovatel’ov občianskeho vzdelávania dospelých v Dánsku môžeme rozdelit' do šiestich základných kategórií:

- akademici v oblasti výskumu na univerzitách - formovanie teoretického a konceptuálneho rámca občianskeho vzdelávania dospelých a realizácia empirického výskumu;

- vysokoškolský učitelia - podiel’anie sa na vyššie uvedených oblastiach formálneho vzdelávania, postupne začleňujú občianske vzdelávanie do kurikula;

- orgány miestnej samosprávy - formulácia a realizácia rôznych foriem integračnej politiky alebo začlenenia, najmä, no nie výlučne imigrantov;

- oblast' neformálneho vzdelávania - zameranie najmä na realizáciu projektov a školení, ktoré súvisia s občianskym vzdelávaním v najširšsom zmysle;

- mimovládne organizácie - záujem o občianske vzdelávanie;

- Dánske ministerstvo školstva a mestské úrady, ktoré regulujú riadia formálne vzdelávanie (Haas, 2015).

Primárnym ciel'om týchto poskytovatel'ov je podpora aktívneho občianstva a s tým spojený rozvoj občianskej spoločnosti. Zaujímavým a inšpiratívnym faktom je možnost' študovat' na vysokých školách magisterský študijný odbor, ktorý sa zameriava na občianstvo a vzdelávanie.

Samotný neformálny systém edukácie v Dánsku zabezpečujú:

- Ludové vysoké školy - folkehojskole - školy, ktoré ponúkajú dlhodobé aj krátkodobé kurzy pre študentov a sú špecifické vzájomným vzdelávaním. Základnou črtou týchto škôl je sloboda. Sloboda ponúkat' vzdelávanie pre všetkých, bez rozdielu rasy a náboženstva a umožnit' študentovi slobodne sa rozhodnút' pre akýkolvek študijný predmet. (www.hojskolerne.dk).

- Večerné školy a študijné združenia - sú inštitúcie, ktoré poskytujú dobrovol'né vzdelávanie dospelých prostredníctvom prednášky, klubov a rôznych aktivít, ktoré vedú účastníka $\mathrm{k}$ zodpovednosti za svoj život, k aktívnemu občianstvu a stým spojenej účasti jedinca na spoločenskom živote. Témy vzdelávania vo večerných školách sú rôzne napr.: šport, filozofia, náboženstvo, politika a iné. 
- Denné l'udové stredné školy - školy ponúkajú programy tzv. „učit’ sa pre zábavu“, sú to formy vzdelávania sa hrou a taktiež ponúkajú prípravné vzdelávanie dospelých, ktorému sme sa venovali vyššie.

- Univerzitné externé pracoviská - univerzity formou prednášok vzdelávajú dospelých, čím rozširujú svoje uskutočňované výskumy, pričom každá univerzita si navrhuje vlastný program a k nim náležitý kurz (EAEA, 2011, pp. 8-9).

Mimovládnou inštitúciou, ktorá sa zameriava na podporu demokracie a politického života v Dánsku je Dansk Folkeoplysnings Samråd-Dánska asociácia pre vzdelávanie dospelých. Asociácia zastupuje 32 členských organizácií, s ktorými sa snažia verejnosti poskytovat' aktuálne informácie o dianí v spoločnosti. Prostredníctvom programov a spolupráce $\mathrm{s}$ inými inštitúciami zabezpečuje neformálne vzdelávanie dospelých.

Organizácia bola založená počas 2. svetovej vojny v roku 1941 za účelom posilnenia občianskych práv a hodnôt. Úlohou organizácie bolo šírit' medzi obyvatel'mi vedomosti o jazyku, kultúre a zároveň podporovat' demokraciu. Organizovala večerné kurzy, ktoré boli bezplatné a určené pre všetkých obyvatel'ov. Počas svojej pôsobnosti organizovala inštitúcia rôzne kampane a poskytovala verejnosti informácie týkajúce sa aktuálnych problémov. $\mathrm{V}$ súčasnosti ponúka kurzy na podporu účasti občanov na tvorbe demokracie a ich aktívne podiel'anie sa na utváraní spoločnosti a rozširuje kultúru krajiny medzi migrantov. Kurzy sú zamerané na novodobé problémy ako sú digitalizácia, globálne zmeny a zdravý životný štýl l’udí, tieto kurzy sú spoplatnené účastníkmi vzdelávania (www.dfs.dk).

Občianske vzdelávanie dospelých v Dánsku je prevažne orientované na mladých dospelých l'udí, u ktorých absentuje aktívna účast' na politickom živote. Politický nezáujem u mládeže spôsobuje, že sa u nich stráca prehl'ad o tom, čo je demokracia. Vládou prijatá reforma $v$ roku 2007 zabezpečila, že občianske vzdelávanie je určené pre všetkých: deti, mládež a dospelých. V školách sa posilnilo vyučovanie k občianstvu, aby sa predchádzalo radikalizácii voči príslušníkom cudzích štátov (www.eng.uvm.dk).

V dôsledku imigrácie sa občianske vzdelávanie dostalo z časti do formálneho vzdelávania dospelých, ktoré sa uskutočňuje prostredníctvom jazykových škôl. V školách sa vyučuje dánsky jazyk, čím sa podporuje zamestnanost' cudzincov a ich aktívna účast' na tvorbe dánskej spoločnosti (www.bpb.de).

Dánsko je krajina kde sa rozširovanie zručností a vedomostí spája s pracovnou činnost'ou. Organizácie majú vzdelávanie zamestnancov často zahrnuté už $\mathrm{v}$ organizačných plánoch a je zabezpečené $\mathrm{v}$ kolektívnych zmluvách. Zmeny súvisiace $\mathrm{s}$ trhom práce požadujú stále nové zručnosti od zamestnancov, čo spôsobuje dopyt po vzdelaní. Na základe týchto potrieb stanovila vláda hlavné ciele celoživotného vzdelávania a d’alšieho vzdelávania dospelých a to týmto spôsobom: 
- každý by sa mal zapojit' do celoživotného vzdelávania,

- vzdelávanie dospelých a d'alšie vzdelávanie musia byt' účinné a flexibilné. Vzdelávanie musí podporovat' dobré pracovné príležitosti pre jednotlivcov, dobrú konkurencieschopnost' v podnikoch a vysokú zamestnanost' a prosperitu v spoločnosti,

- vzdelávanie dospelých a d’alšie vzdelávanie má všetkým poskytovat' príležitosti na zlepšenie schopností - v neposlednom rade tým, ktorí majú najnižšiu úroveň formálneho vzdelávania,

- vzdelávanie dospelých a d'alšie vzdelávanie musí odrážat' zmeny v kvalifikačných požiadavkách na zamestnanca a v potrebách na trhu práce (www.eng.uvm.dk).

Stratégia nehovorí jasne o občianskom vzdelávaní dospelých, obsahuje však zabezpečenie globálneho rozhl'adu, rozvoj demokracie a posilňuje spoločenskú súdržnost'.

\section{Zhrnutie}

Občianske vzdelávanie dospelých v uvedených krajinách má na prvý pohl'ad množstvo špecifík. Uvedomujeme si, že nie je možné uvedené dáta zovšeobecňovat', avšak aj napriek tejto skutočnosti si dovolíme konštatovat', že v rámci jednotlivých modelov realizácie občianskeho vzdelávania dospelých nachádzame niekol'ko prvkov, ktoré predstavujú akési spoločné znaky:

- bohatá historická tradícia a častá prepojenost' občianskeho vzdelávania dospelých s občianskym vzdelávaním detí a mládeže,

- l'udové vysoké školy,

- výrazný vplyv tretieho sektoru,

- existencia národných inštitúcií, ktoré poskytujú občianske vzdelávanie pre rôzne ciel’ové skupiny a zároveň vytvárajú akúsi podporu pre ostatných poskytovatel'ov,

- vplyv aktuálnych trendov (ako napríklad digitalizácia), ktorá ovplyvňuje formy súčasného občianskeho vzdelávania dospelých naprieč celou Európou, respektíve svetom,

- vstup štátu do realizácie občianskeho vzdelávania (financovanie, strategické dokumenty, a pod.).

Uvedené modely zároveň považujeme za akúsi inšpiráciu pre podmienky Slovenska, či Českej republiky. Vychádzajúc zo SWOT analýzy aktuálneho stavu občianskeho vzdelávania dospelých na Slovensku (Sládkayová, 2019) môžeme konštatovat', že občianskemu vzdelávaniu dospelých by pomohla práve lepšia metodická podpora pre poskytovatel'ov tretieho sektora, ako aj odborná príprava lektor/odborníkov v tejto oblasti. Akýmsi odporúčaním by teda mohlo byt' vytvorenie centrálnej/národnej inštitúcie, ktorá by vytvárala priestor práve na poradenstvo pre jednotlivých poskytovatel'ov občianskeho vzdelávania dospelých, prípadne aspoň národného portálu, ktorý by prepájal všetky vzdelávacie inštitúcie a organizácie a ich jednotlivé zameranie a typy vzdelávacieho programov a služieb dospelým občanom na makro a mikroúrovni. 
Na druhej strane je však potrebné postupovat'vel'mi opatrne pri preberaní jednotlivých modelov občianskeho vzdelávania dospelých. Je potrebné si uvedomit’ ich špecifiká, ako špecifiká jednotlivých systémov v vzdelávania a ich historický východísk, ktoré do značnej miery d'alej ovplyvňujú celkovú realizáciu jednotlivých druhov vzdelávania.

Na popise situácie vzdelávacích systémov a štruktúr vo vybraných krajinách Európy je každopádne vidiet', že štáty s novodobými európskymi ciel'mi týkajúcimi sa posily aktívneho občianstva a občianskeho vzdelávania dospelých postupne pracujú. $Z$ analýzy je zrejmé taktiež prepojenie jednotlivých subsystémov d’alšieho vzdelávania dospelých (profesijného, občianskeho, ale aj záujmového vzdelávania dospelých) a ich vzájomná priepustnost' a nadväznost', ktorá sa premieta najmä do kompetencií občanov. Tí nakoniec môžu mat' vel'mi variabilné uplatnenie v pracovnom aj osobnom živote, takmer v celej spoločnosti.

Aj napriek tomu, že niektoré krajiny stoja, s ohl'adom na úroveň občianskeho vzdelávania dospelých, na európskej špičke (ako sú napríklad severské štáty Európskej únie), všetky krajiny bez rozdielu majú určité rezervy vo svojich systémoch vzdelávania. Tieto rezervy sa jednotlivé krajiny snažia zlepšit’ aj s ohl'adom na novodobé trendy a svoju aktuálnu situáciu v krajine. Schopnost' pružne reagovat' na aktuálne spoločenské zmeny a najmä následná implementácia plánovaných, aktuálnych výziev celoživotného učenia, vrátane podpory občianskeho vzdelávania dospelých, do občianskej reality v konečnom dôsledku ovplyvní nie len vzdelanostnú úroveň občanov jednotlivých štátov, ale taktiež aj ekonomiku a celkovú prosperitu krajiny.

\section{Bibliographic references}

Andragoski centrum Republike Slovenije. (2021). https://www.acs.si/o-nas/

Beran Sladkayova, M. \& Neusarova, J. (2021). Modely obcianskeho vzdelavania dospelych. Banska Bystrica: Belianum. ISBN 978-80-557-19061.

EAEA. (2011). Country report Denmark. Helsinky: European association for the education of adults. https://eaea.org/wpcontent/uploads/2018/01/denmark_country-report-on-adult-education-indenmark.pdf

EAEA. (2011). Country report Germany. Helsinky: European association for the education of adults. https://eaea.org/wpcontent/uploads/2018/01/germany_country-report-on-adult-education-ingermany.pdf

Epravo.cz (2018). Code civil, aneb změny ve francouzském obligačním právu po 1. ř́ijnu 2018. https://www.epravo.cz/top/clanky/code-civil-anebzmeny-ve-francouzskem-obligacnim-pravu-po-1-rijnu-2018-108304.html.

EUROPEAN COMMISSION (2018a). Independent national experts network in the area of adult education/adult skills. Full Country Report - Germany. https://epale.ec.europa.eu/sites/default/files/2021-02/25.01.2019_ALN_DETOC.pdf 
EUROPEAN COMMISSION (2018b). Independent national experts network in the area of adult education/adult skills. Full Country Report - France. https://epale.ec.europa.eu/sites/default/files/2021-02/17.10.19_ALN_FRTOC.pdf.

EUROPEAN COMMISSION (2018c). Independent national experts network in the area of adult education/adult skills. Full Country Report - Slovenia. https://epale.ec.europa.eu/sites/default/files/2021-02/11.01.19_ALN_SITOC.pdf.

Haas, C. (2015). Citizenship Education in Denmark. Bonn: Bundeszentrale für politische Bildung. http://www.bpb.de/veranstaltungen/netzwerke/nece/214058/citizenshipeducation-in-denmark

INFORMACNI CENTRUM VLADY CR (2009). Deklarace prav lidskych a obcanskych. https://icv.vlada.cz/assets/udalosti/Deklarace-prav-lidskych-aobcanskych.pdf.

Kopecky, M. (2011). Obcanske vzdelávani dospelych v Evrope. Povaha, funkce a vybrane narodna priklady. Praha : MŠMT. http://www.msmt.cz/file/15059

LA LIGUE DE L'ENSEIGNEMENT (n.d.). Qui-sommes-nous. https://www.laligue22.org/-Qui-sommes-nous-.html.

PILNY, I. (2020). Hledame nove Amose. Ucit nebo vzdelavat? Praha: Olympia. ISBN 978-80-7376-594-1.

Sladkayova, M. (2019). Obcianske vzdelavanie dospelych. Banská Bystrica:

Belianum. ISBN 978-80-557-1535-3.

Vymetal, J., Diacikova, A. \& Vachova. M. (2005). Informacni a znalostni management v praxi. Praha: LexisNexis CZ. ISBN 80-86920-01-1.

www.adb.de

www.bmi.bund.de

www.bpb.de

www.gov.pl

www.zagranica.org.pl

www.civispolonus.org.pl

www.civispolonus.org.pl

www.hojskolerne.dk

www.dfs.dk

www.eng.uvm.dk

www.eng.uvm.dk

Mgr. Michaela Beran Sládkayová, PhD.

Department of pedagogy and andragogy

Matej Bel University in Banská Bystrica

Faculty of Education

Ružová 13, 97411 Banská Bystrica

Slovak Republic

michaela.sladkayova@umb.sk 
Mgr. Jana Neusarová, Ph.D.

Department of andragogy

University of Jan Amos Komensky in Prague

Roháčova 63, 13000 Praha 3

Czech Republic

neusarova.jana@ujak.cz 